\title{
Bazı Yaygın Fiğ (Vicia sativa L.) Çeşitlerinde Olgunlaşmamış Embriyo Eksplantlarından Adventif Sürgün Rejenerasyonu*
}

\author{
Satı ÇÖÇÖ Serkan URANBEY ${ }^{1}$ Cengiz SANCAK
}

Geliş Tarihi: 07.01.2003

\begin{abstract}
Özet: Yüksek oranda bír adventif sürgän rejenerasyonu elde etmek için 8 ayri fiğ çeşidinde olgunlașmamis kotiledon ve embriyo eksenleri degișik oranlarda büyüme düzenleyiciler içeren MS besin ortamında kültüre alınmıştir. Olgunlaşmamiş embriyo eksenlerinden en yüksek sügân rejenerasyonu \%95 ile Kubilay çeșidinden $4 \mathrm{mghl} 6$ benzilaminopurin (BAP) ve $0.25 \mathrm{mg} / \mathrm{a}$-naftalenasetik asit (NAA) içeren besin ortamından elde edilirken; eksplant başına en fazla sürgün 9.47 adet ile Sanelçi çeşidinden $2 \mathrm{mg} / \mathrm{BAP}$ ve $0.25 \mathrm{mg} / \mathrm{l}$ NAA Içeren besin ortamindan elde edilmiştir. Olgunlașmamıs kotiledon eksplantiarında ise hiç sörgün rejenerasyonu elde edilememiştir. Gelișen bu surgünler daha sonra, kesilerek $2.5 \mathrm{mg} / \mathrm{I}$ indole-butyric asit (IBA) içeren MS besin ortamında kōklendirilmiştír. Son olarak. köklenen sürgünler saksilara aktarilmiştır.
\end{abstract}

Anahtar Kelimeler: fiğ, doku költüru, adventif sürgün rejenerasyonu, olgunlaşmamiş embriyo

\section{Adventitious Shoot Regeneration from Immature Embryo Explants of Some Common Vetch (Vicia sativa L.) Cultivars}

\begin{abstract}
Immature embryo axes and immature colyiedons of eight vetch cultivars were cultured on MS medium containing various combinations of growth regulators for adventitious shoot regeneration. The highest frequency of immature embryo axes producing adventitious shoots $(95 \%)$ was obtained from Kubilay cultivar on a medium containing $4 \mathrm{mg} / \mathrm{l}$ 6-benzylaminopurine (BAP) and $0.25 \mathrm{mg} / \mathrm{l} \alpha$-naphtaleneacetic acid (NAA); whereas, the highest number of shoots per embryo axis explants $(9,47)$ was achieved from Sarielci cultivar on a media supplemented with 2 mg/l BAP and $0.25 \mathrm{mg} / \mathrm{I}$ NAA. Immature cotyledon explants did not resulted in shoot regeneration. Regenerated shoots $(1-2 \mathrm{~cm})$ were excised and rooted in MS medium containing $2.5 \mathrm{mg} / \mathrm{l}$ indole-butyric acid (IBA). Rooted plantlets were finally transferred to compost.
\end{abstract}

Key Words: vetch, tissue culture, adventitious shoot regeneration, immature embryo

Giriş

Ülkemizde yem bitkileri içerisinde tarımı en yaygın olan bitki türlerinden bir tanesi fiğlerdir. Fiğ türleri içerisinde en fazla yetiştirilen ise yaygın fiğ (Vicia sativa)'dir. Yaygın fiğin anavatanı. Akdeniz Havzası ve Bati Asya'dir. Günümüzde; tüm Akdeniz alkeleri, Orta ve Kuzey Avrupa ülkeleri, Yeni Zelanda, Kuzey ve Gûney Amerika, Guney Afrika, Doğu Asya ve Avustralya'da yaygın bir sekilde tarımı yapılmaktadır (Sağlamtimur ve ark. 1990), Olkemizde Cumhuriyetin ilk yillarında 19.800 ha ekim alanına sahip olan yaygın fiğ, bugün 235.000 ha ekim alanına ulaşmış olup bu oran yem bitkileri ekim alanınin \%25'ini olușturmaktadır (Anonim 1999).

Fiğ, genel olarak kıyı bolgelerimizde yeșil ve kuru ot ic bölgelerimizde ise dane ( $=$ tohum) üretimi amaciyla yetiştirimektedir. Gerek otu, gerekse tohumu iyi bir hayvan yemidir. Fiğ ince sapli, bol yapraklı ve hayvanların severek yedikleri besin maddelerince zengin ot verir. Çok lezzetli ve besleyici olan fiğ otu, biçim zamanına göre değișmekle birlikte \%12-24 oraninda ham protein içerir. Bunun yanı sıra, daneleri de $\% 20$ civarında protein içerdiğinden çeșitli hayvanların beslenmesinde yoğun yem olarak da kullanılabilir. Ayrıca, tohumlardan arta kalan fiğ samani da hayvanlar için iyi bir yem olup, yapısında ortalama \%5-6 protein içermektedir. Fiğ toprağı fazla yormayan bir bitkidir. Aksine ot veya tohum için yetiştirilen fiğ, bıraktığı kök ve anız artıkları ile toprağın organik madde miktarını artırıken, köklerinde yaşayan Rhizobium bakterileri de havanin serbest azotunu toprağa bağlarlar. Böylece, yetiștíildikleri toprağı azotlu bileşikler yönünden zenginleștirifler. Ciçeklenme döneminde sürülerek toprağa karıştırılan fiğ, sağladığı organik madde ve azot sayesinde ağır toprakları gevsetir, hafif toprakların su tutma kapasitelerini artirır ve toprakların yapısını düzeltir.

Soya (1991) yeşil gübre olarak ekilen fiğin dekara ortalama $400 \mathrm{~kg}$ organik madde ve $10 \mathrm{~kg}$ saf azot sağladığını saptamıștır.

Geleneksel tahıl-nadas sisteminin uygulandığı kurak bölgelerimizde, tahıl hasadından sonra yeniden tahıl ekimine kadar tarla yaklaşık 15 ay boş kalmaktadır. Son yillarda yapilan araştırmalarda toprak yapisinin uygun olduğu bölgelerde tahıl nadas sisteminde boş bırakılan nadas yilında fiğin saf veya tahillar lie karıșım halinde yetiştirilebileceği saptanmıştır. Böylece nadas yilinda hem toprak erozyonu önlenmekte, hem de buğday veriminde bir azalma meydana gelmemektedir. Yıllık yağıșı 400 mm'den fazla olan bëlgelerde ve taban alanlarda fiğ ekimi ile büyük bir yem üretimi olanağı bulunmaktadır. Kaliteli kaba yem açığının büyok boyutlarda olduğu ülkemizde bu üretimin önemi daha da artmaktadır (Açıkgöz 1991)

\footnotetext{
- Yuksek Lisans Tezi'nden hazırlanmiştır

'Ankara Univ. Ziraat Fak. Tarla Bitkileri Bölumu-Ankara
} 
Buton bu olumlu tarımsal özelliklerine karșn fiğ turleninin tarmı tehdit altındadır. Bundan dolayi hastalik ve zararlilara dayanikli, yöksek ot ve tohum verimine sahip erkenci çeşitlerin geliştirilmesi son derece unem taşımaktadir. Ancak klasik bitki ıslahı teknikleriyle hastalik ve zararillara dayaniklilik başta almak uzere, çeşitlerin diḡer birçok tarımsal özelliklerini iyileştirmede onemil sinırlamalarla karşılaşilmaktadir (Ozcan ve Ozgen 1996). Otè yandan, son yıllarda geliştirilen bitki genetik mühendisliği teknikleriyle hastalık ve zararhiara dayanıkı bitki çeşitleri kolaylıkla üretildiği gibi; yulksek verim kalite ve erkencilik yönünden de ônemli adımiar atılmıştır. Genetik mühendisliği tekniklerinin bitki islahinda kullanilabilmesindeki temel gereklilik ise, költöre alınan bitkí doku, organ ve hücrelerinden yüksek oranda bir adventif sürgün rejenerasyonunun elde edilmesidir (Sancak ve ark. 2000).

Bu çalışmanın amaci da; Turkiye'de ürefimi yapılan yaygin fiğ çeşitlerinde gen aktarımına uygun yüksek oranda adventif sürgün rejenerasyonu sağlayan bîr yöntemin geliştirilmesidir.

\section{Materyal ve Yöntem}

Araştirma Ankara Üniversitesi Ziraat Fakkúltesi Tarla Bitkileri Bölümol Biyoteknoloji Laboratuvarlarında yorotolmáştor. Bitki materyali olarak Kara elçi (Erzurum L147), Sarı elçi, Kubilay-82, Orem-79, Emir, Uludağ, Nilüfer ve Cubuk (Populasyon) yaygın fiğ çeșitleri kullanimıştır. Baklaların yúzey sterilizasyonu; olgunlaşmamış ambriyo eksenler ve kotiledonlann izolasyonu Ozcan ve ark. (1993) ile Sancak (1999)'in arif ettiği gibl yapilmıştr. Tarlada yetiştirilen fiğ çeșitlerinden tam iriliğine ulaşmış, henüz parlak yeşil ve yumuşak tohumiarı içeren baklalar hasat edilmiștir (Sekil 1a,1b). Hasat edilen baklaiar, içerisinde \%100'läk ticari çamașı suyu (ACE) bulunan, 250 ml'lik steril kavanozlar içerisinde $\mathbf{2 5}$ dakîka süreyle sterilizasyona tabi tutulmuştur. Yüzey sterilizasyonundan sonra baklalar steril sal su lie 4 defa durulanmıştır. Baklalar, bir petri kutusu içerisinde bistüri yardimryla algunlaşmamış tohumlara zarar vermeden ortadan boylamasına ikiye ayrılmıștır. Bakladan çıkartılan olgunlaşmamış tohumların tohum kabuğu bistâri yardımıla açilarak olgunlaşmamış embriyolar izole edilmiştir. Daha sonra, olgunlaşmamış kotiledoniarın 2/3'lük uç kısmı kesilip atılarak, kalan 1/3'lük kısım umbriyo eksenlerinden kopma noktasi uste gelecek ફ̧ekilde kati rejenerasyon artamına yerleştirilmiștir. Aynca, embriyo eksenleri de kotiledoniardan koparildığı kısım besin ortamina temas edecek şekilde inkübe edlimiştir. Rejenere olan sürgünler $1-2 \mathrm{~cm}$ uzunluğuna geldiklerinde kesilerek 0.50-2.50 mg// IBA içeren MS besin ortarniannda kőklendirilmeye alinmiş, her magentaya 5 eksplant yerleştỉilmiștir.

Izole edilen tum eksplantiar lçerlerinde $35 \mathrm{mi}$ katı rejenerasyon ortamı bulunan petri kutularında $(100 \times 10$ inm) alt kaltür yapılmaksızın kültüre alınınıștır. Sürgün veren eksplant yüzodeleri ve eksplant başina sürgün sayılan kültür bașlangıcından 8 hafta sonra belirlenmiştír. Çalışmada 6 farklı ortam 8 farklı çeșitte 4 tekerrulril olarak denenmiştir. Embriyo ekseni ile yapilan çalışmalarda her bir tekerrilr için 5 eksplant kalture alınırken; olgunlaşmamıs kotiledonlarda ise her bir tekerrurde 10 eksplant kultüre alınmıştır. Calışmadan elde edilen veriler bilgisayarda "SPSS for Windows" program lie tesadof parsellerinde bulünmōs parseller deneme desenine gore analiz edilmiştir. Muamele ortalamaları MSTAT-C bilgisayar programı kullanilarak Duncan testl ile karşılaştınimaştır. Köklendirme çalışmaları ise țesadúf parselleri deneme desenine göre 3 tekerrürla olarak kurulmuștur. Yüzde deg̈erleri istatistik analizi yapilmadan önce "arcsin transformasyon" una tabi futulmuşlur (Snedecor ve Cochran 1967).

Rejenerasyon ortamı icerisinde MS (Murashige ve Skoog 1962) mineral tuz ve vitaminleri ile $\% 3$ sukroz, $\% 0.7$ agar, 0.25-4 mg/l 6-benzilaminopurin (BAP) ve 0.25$4 \mathrm{mg} / \mathrm{a}$-naftalenasetik asit (NAA) bulunmaktadir. Besin ortamlaninin pH'sı $1 \mathrm{~N} \mathrm{NaOH}$ ya da $1 \mathrm{~N} \mathrm{HCl}$ kullanitarak 5.8'e ayarlandiktan sonra 1.2 atmosfer basinç altinda ve $121{ }^{\circ} \mathrm{C}$ 'de 20 dakika tutularak steril edilmiştir. Tum kaitorler beyaz florasan ışığında 16 saat ıșik ve 8 saatlik karanlık fotoperiyotta $24^{\circ} \mathrm{C}$ 'de tutulmuştur.

\section{Bulgular ve Tartışma}

Olgunlaşmamış kotiledonlardan adventif sûrgün rejenerasyonu: In vitra adventif sürgün rejenerasyonu elde etmek amacıyla tarlada gelişen bitkilerden alınan baklalardan izole edilen olgunlaşmamiş kotiledon eksplantlan deģişik oranlarda BAP ve NAA içeren MS ortamlarında kolture alınmıștır. Kültür bașlangıcindan 3 hafta sonra bütün eksplantlar üzerinde kallus oluşmuş, ancak bu kallusiar úzerinde adventif sürgün uçlanı gözlenmemiştir (Şekil 1c).

Olguniaşmamış embriyo eksenlerinde sürgün rejenerasyonu: Yaksek oranda bir adventif sürgün rejenerasyonu elde etmek amaciyla tarlada gelişen bitkilerden alınan olgunlașmamış embriyo eksenleri değişik oranlarda buyûme düzenleyiciler içeren ortamlarda kültüre alınmıșlardır. Çalışmada BAP ve NAA'in değișik kombinasyonlarinin ceşitlere göre adventif sürgün rejenerasyonuna etkisi araştırımıştır. Olgunlaşmamış embriyo eksenlerinde ilk 10 günlük dönemde önceden varolan meristemlerden kuvvetli sürgünler gelişmiş̧tir. Bu sürgünler adventif olmadığından kesilerek uzaklaştırıimıştır. Kültür bașlangıcından 10-15 gün sonra sıkı yapılı morfogenik yeşil kallusiar meydana gelmiştir. Ôf hafta içerisinde de bu kalluslar üzerinde sook sayıda adventif sürgün uçlarinin gelişimi gözlenmiştir (Şekil 1d,e). Ortamların, çeşitierin ve interaksiyonun sürgün oluşturan eksplant yüzdesine ve eksplant başına sürgün sayısına etkisi 0.01 düzeyinde ónemli bulunmuștur. Cizelge 1'de Farklı BAP ve NAA konsantrasyonlarınin fiğ peșitlerinde olgunlaşmamıș embriyo ekseni eksplantinda sürgün oluşturan eksplant yuzdesine ait, Çizelge 2'de ise eksplant başına sürgán sayısına ait değerler görälmektedir. Çizelgelerden de anlaşılacağı tizere farklı BAP ve NAA konsantrasyonlarinin çeșitlere göre sürgün gelişimine etkisinde ǒnemli farklıık gözlenmiştir $(p<0.01)$.

Olgunlaşmamiş embriyo ekseni eksplantında sürgün oluşturan eksplant yüzdesi en fazla Çubuk peşidinde 


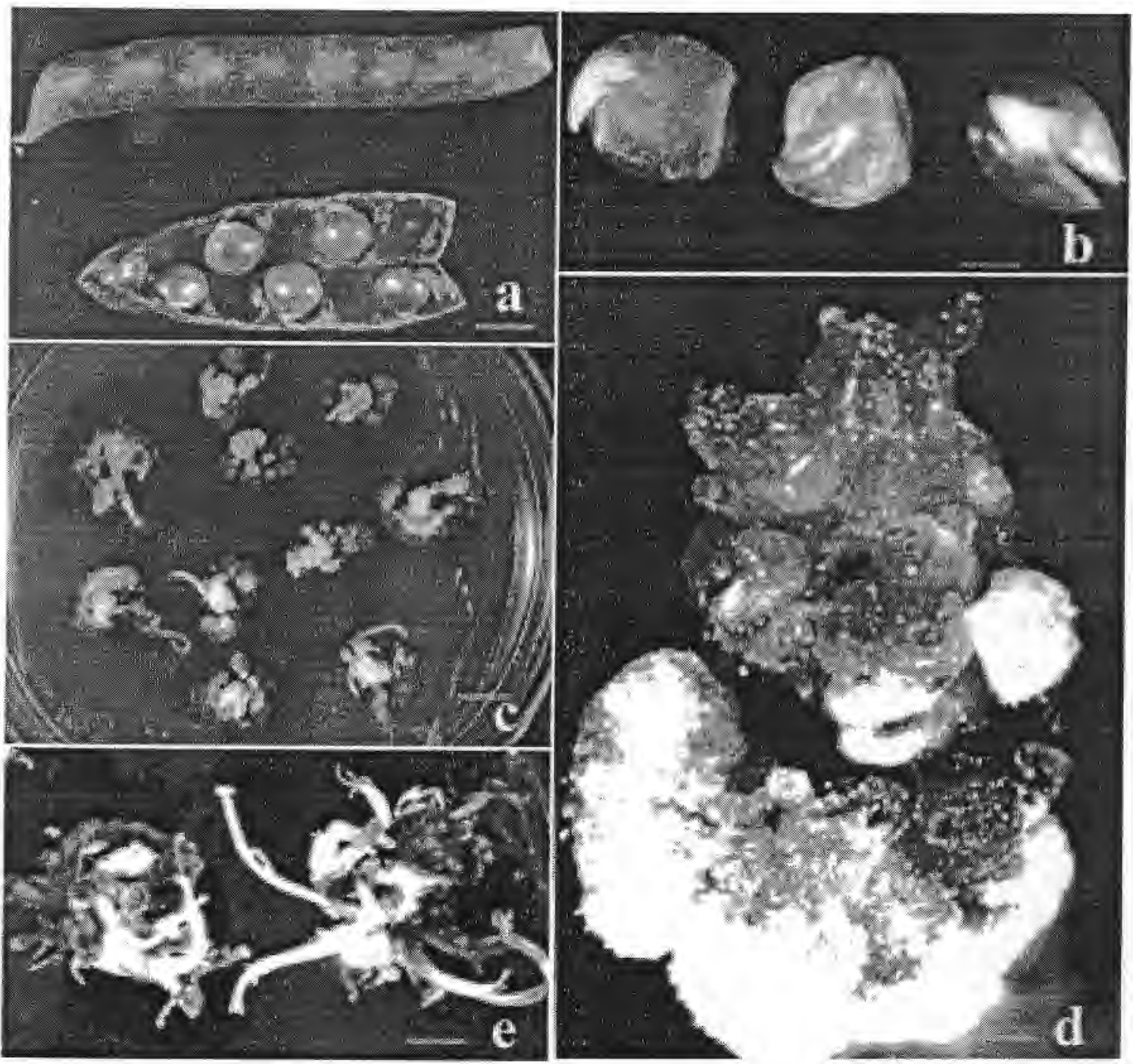

Şekil 1. Yaygın fiğde olgunlaşmamış embriyo eksplantlarından kallus oluşumu ve adventif sürgün rejenerasyonu $(a, b)$ adventif sürgün rejenerasyonu için kültüre alınan fiğ bakla, olgunlașmamış kotiledon ve embriyo ekseni (bar $=5 \mathrm{~mm}, 2 \mathrm{~mm}$ )

(c) kültür başlangıcından 5 hafta sonra olgunlaşmamış kotiledon eksplantları (bar=7mm)

(d, e) Kubilay çeşidinde olgunlașmamiş embriyo ekseni eksplantında kallus olușumu ve adventif sürgün rejenerasyonu (bar $=1.5 \mathrm{~mm}, 6 \mathrm{~mm}$ )

Çizelge 1. Farklı BAP ve NAA konsantrasyonlarının değişik fiğ çeşitlerinin olgunlaşmamış embriyo eksenlerinden adventif sürgün oluşum oranına etkisi

\begin{tabular}{|c|c|c|c|c|c|c|c|c|c|c|}
\hline \multirow{2}{*}{\multicolumn{2}{|c|}{$\begin{array}{c}\text { Büyüme } \\
\text { düzenleyicileri } \\
\text { (mg/l) }\end{array}$}} & \multicolumn{9}{|c|}{ Sürgün oluşturan eksplant yüzdesi (\%) } \\
\hline & & \multicolumn{9}{|c|}{ Çeşitler } \\
\hline BAP & NAA & Çubuk & Uludağ & Nilüfer & Örem & Emir & Kubilay & Sarieiçi & K. elçi & Ortam. Ort. \\
\hline 0.25 & 2 & $0.0^{*} B$ & $0.0^{\circ} \mathrm{B}$ & $0.0^{0} \mathrm{~B}$ & $0.0^{\circ} \mathrm{B}$ & $35.0^{0 \mathrm{C} A}$ & $50.0^{\circ} \mathrm{A}$ & $0.0^{\circ} \mathrm{B}$ & $0.0^{*} B$ & 10.62 \\
\hline 0.25 & 4 & $0.0 \mathrm{C}$ & $0.0^{\circ} \mathrm{C}$ & $0.0^{\circ} \mathrm{C}$ & $20.0^{\circ C} B$ & $25.0^{6 C} B$ & $50.0^{\circ} \mathrm{A}$ & $0.0^{\circ} \mathrm{C}$ & $0.0 \mathrm{C}$ & 11.87 \\
\hline 1 & 2 & $0.0 \mathrm{C}$ & $40.0^{2} \mathrm{~A}$ & $50.0^{2} A$ & $50.0^{2} A$ & $20.0^{C} B$ & $15.0^{6} B$ & $30.0^{2} A B$ & $0.0 \mathrm{C}$ & 25.62 \\
\hline 2 & 0.25 & $10.0 B C$ & $5.0^{\circ} B C$ & $450^{\mathrm{a} A}$ & $150^{\circ} B$ & $40.0^{\operatorname{abc} A}$ & $35.0^{10 \mathrm{~A}} \mathrm{~A}$ & $55.0^{\mathrm{A}} \mathrm{A}$ & $0.0 \mathrm{C}$ & 25,62 \\
\hline 2 & 1 & $0.0 \mathrm{C}$ & $5.0^{\circ} \mathrm{C}$ & $25.0^{2} \mathrm{~B}$ & $0.0^{\circ} \mathrm{C}$ & $55.0^{\mathrm{ab}} \mathrm{A}$ & $50.0^{\circ} \mathrm{A}$ & $35.0^{\mathrm{a}} A B$ & $0.0 \mathrm{C}$ & 21.25 \\
\hline 4 & 0.25 & 0.00 & $10.0^{\circ} \mathrm{D}$ & $35.0^{3} \mathrm{C}$ & $45.0^{20} B C$ & $65.0^{2} \mathrm{~B}$ & $95.0^{\mathrm{d}} \mathrm{A}$ & $50.0^{2} B C$ & $0.0 D$ & 37,50 \\
\hline \multicolumn{2}{|c|}{ Çeşit. Ort. } & 1.66 & 10.00 & 25.83 & 21.66 & 40.00 & 49.16 & 28.33 & 0.0 & - \\
\hline
\end{tabular}

Ayni sütunda farklı küçük harflerle gösterilen ortalamalar arasındaki fark $p<0.05$ dúzeyinde önemiidir

Aynı satırda farkıı büyük harflerle gösterilen ortalamalar arasındaki fark $p<0.05$ düzeyinde önemlidir

*: aynı sütun içerisinde farklılık istatistiksel olarak önemli bulunmamiştir 
Çizelge 2. Farklı. BAP ve NAA konsantrasyonlannin değişik n̄g çeşitlerinin olgunlaşmamış embriyg eksenlerinden adventif sürgün say'sina etkisi

\begin{tabular}{|c|c|c|c|c|c|c|c|c|c|c|}
\hline \multirow{2}{*}{\multicolumn{2}{|c|}{$\begin{array}{c}\text { Bayame } \\
\text { duzenleyicileri } \\
\text { (mg/l) }\end{array}$}} & \multicolumn{9}{|c|}{ Eksplant başına surgün sayısı (adet) } \\
\hline & & \multicolumn{9}{|c|}{ Çeşitler } \\
\hline BAP & NAA & Çubuk & Ultodag & Nildfer & Orem & Emir & Kubilay & Sanelçi & K. elçi & $\begin{array}{l}\text { Ortam. } \\
\text { Ort. }\end{array}$ \\
\hline 0.25 & 2 & $0.00 * B$ & $0.00^{\circ} \mathrm{B}$ & $0.00^{\circ} \mathrm{E}$ & $0.00^{\circ} \mathrm{B}$ & $1.66^{\circ} \mathrm{B}$ & $4.00^{20} A$ & $0.00^{C} B$ & $0.00^{\circ} B$ & 0.71 \\
\hline 0.25 & 4 & $0.00 \mathrm{~B}$ & $0.00^{\circ} \mathrm{B}$ & $0.00^{\circ} B$ & $1.38^{60} \mathrm{AB}$ & $2.26 \overline{A B}$ & $3.33^{\operatorname{manc} A} \mathrm{~A}$ & $0.00^{\circ} B$ & $0.00 \mathrm{~B}$ & 0.93 \\
\hline 1 & 2 & $0.00 \mathrm{D}$ & $6.03^{\mathrm{A}} \mathrm{A}$ & $4.26^{\mathrm{d}} \mathrm{AB}$ & $5.93^{\circ} \mathrm{A}$ & $2.88 \mathrm{BC}$ & $1.50^{\circ} C D$ & $3.83^{\circ} \mathrm{AB}$ & $0.00 D$ & 3.05 \\
\hline 2 & 0.25 & $1.00 C D$ & $1.50^{\circ} \mathrm{BCD}$ & $3.58^{\circ} \mathrm{B}$ & $1.26^{c} C D$ & $3.08 B C$ & $2.57^{20} B C$ & $9.47^{\circ} A$ & $0.00 \mathrm{D}$ & 2.80 \\
\hline 2 & 1 & $0.00 \mathrm{C}$ & $0.50^{4} \mathrm{C}$ & $3.63^{\circ} B$ & $0.00^{\circ} \mathrm{C}$ & $3.27 \mathrm{~B}$ & $3.56^{200} B$ & $5.88^{\circ} \mathrm{A}$ & $0.00 \mathrm{C}$ & 2.10 \\
\hline 4 & 0.25 & $0.00 \mathrm{C}$ & $1.50^{\circ} B C$ & $2.88^{2} B$ & $3.66^{\circ} A B$ & $2.13 B C$ & $5.56^{2} A$ & $5.10^{9} \mathrm{~A}$ & $0.00 \mathrm{C}$ & 2.60 \\
\hline \multicolumn{2}{|c|}{ Cessit Ort } & 0.17 & 1.59 & 2.39 & 2.12 & 2.54 & 3.42 & 4.04 & 0.00 & - \\
\hline
\end{tabular}

Aymı sôtunda farklı kücük harfierle gösterilen ortalamalar arasındaki fark $\mathrm{p}<0.05$ düzeyinde onnemlidir

Aynı satırda farklı büyŭk harflerle gōsterilen ortalamalar arasındaki fark $p<0,05$ düzeyinde onemlidir

*ayni sotun içerisinde farklılik istatistiksel olarak onemli bulunmamıştır

(\% 10.00) $2 \mathrm{mg}$ B BAP ve $0.25 \mathrm{mg} / \mathrm{NAA}$, Uludăg, Nilufer ve Orem çeşitlerinde (sırasıyla $\% 40.00, \% 50,000$ ve $\%$ 50.00) $1 \mathrm{mg} / \mathrm{l}$ BAP ve $2 \mathrm{mg} / \mathrm{NAA}$, Emir, Kubilay ve Sarielçi çeşitlerinde (sirastyla $\% 65.00, \% 95.00$ ve $\%$ 50.00 ) ise $4 \mathrm{mg} / \mathrm{l} \mathrm{BAP}$ ve $0.25 \mathrm{mg} / \mathrm{NAA}$ içeren MS besin ortamlarından elde edilmiştir. Eksplant başına en fazla sồrgün sayısı ise Çubuk ceșidinde (1 adet) $2 \mathrm{mg} / \mathrm{l}$ BAP ve $0.25 \mathrm{mg} / \mathrm{l}$ NAA, Uludağ $(6.03$ adet), Nilofer ( 4.26 adet) ve Orem (5.93 adet) çeşitlerinde $1 \mathrm{mg} / \mathrm{BAP}$ ve $2 \mathrm{mg} / \mathrm{NAA}$. Emir çeşidinde (3.27 adet) $2 \mathrm{mg} / \mathrm{BAP}$ ve $1 \mathrm{mg} / \mathrm{NAA}$. Kubilay çeșidinde ( 5.56 adet) $4 \mathrm{mg} / \mathrm{l}$ BAP ve $0.25 \mathrm{mg} / \mathrm{l}$ NAA, Sarıe!çi çeşidinde ( 9.47 adet) ise $2 \mathrm{mg} / \mathrm{BAP}$ ve $0.25 \mathrm{mg} / \mathrm{l}$ NAA içeren MS besin ortammindan elde edilmiştir.

Tarımsal oneme sahip genlerin gen aktarım teknikleri lie bitkilere aktariabilmesi için etkili adventif sulrgun rejenerasyon yöntemlerinin geliştirilmesi gerekmektedir. Gen aktarımı yapilan húcrelerden transgenik bitkiler rejenere edilmedikçe, o gen aktarımının hiçbír önemi olmamaktadır. Yayşın fiğin olgunlaşmamıs embriyo eksplantiarinda dana ónce sürgün rejenerasyonu bildirilmemiştir. Ote yandan, önceki çalışmalarda soya (Lazzeri ve ark. 1987), bezelye (Ozcan ve ark. 1993) korunga (Ozcan ve ark. 1996), koca fiğ (Sancak 1999) ve Macar fiği (Sancak ve ark. 2000) gibi baklagillerin olgunlaşmamiş kotiledon ve embriyo eksenlerínden youksek oranlarda adventif sürgün rejenerasyonu elde edilmiştir.' Bütün bu çalışmalar baklagillerde olgunlaşmamış embriyo eksplantlarının rejenerasyon için Iyi bir başlangıç materyali olduğụnu göstermaktedir.

Sekiz ayrı fiğ çeșidinde yapılan bu çalışmada olgunlaşmamış kotileưnlardan túm ortamlarda \% 100 kallus oluşumu elde edilirken, bu kalluslardan sürgün gelişimi elde edilememiştir, Olgunlaşmamış embriyo ekseni eksplantında ise Karaelçi ceşidi hariç diḡer çeșitlerde sürgün gelișimi elde edilmiştir. Natali ve Cavallini (1987), bezelyede yaptıkları çalışmada sürgün rejenerasyonumu en fazla etkileyen faktörün eksplant tipi ve genotip olduğunu belirtmişlerdir. Bu araștirmada olgunlaşmamı kotiledon eksplantinda denemeye alinan 5 farkli bezelye genotipinden sadece 5075 hattinda $2 \mathrm{mg} / \mathrm{l}$
BAP ve $2 \mathrm{mg} / \mathrm{N}$ NAA içeren besin ortamindan surgün rejenerasyonu elde etmişler, diğer çeşit ve ortamlarda sürgūn rejenerasyonu elde ederriemiģlerdir. Olgunlaşmamiş embryo ekseni eksplantinda ise $0.5 \mathrm{mg} / \mathrm{h}$ BAP ve $3 \mathrm{mg} / \mathrm{NAA}$ içeren ortamda 5 genotipte de sürgün rejenerasyonu elde edilemezken, $2 \mathrm{mg} / \mathrm{B}$ BAP ve $2 \mathrm{mg} / \mathrm{l}$ NAA içeren besin ortamında ise tüm genotiplerde sürgün rejenerasyonu elde etmister, $3 \mathrm{mg} / \mathrm{l}$ BAP ve $5 \mathrm{mg} / \mathrm{NAA}$ içeren ortamda ise sadece 5075, Dolce Provenza ve Espresso Generoso cesitlerinde sürgan rejenerasyonu elde etmişlerdir. Aynı tôre ait çeșitler arasında adventif sürgón rejenerasyonu bakımından büyük farklar oldug̃u diğer birçok araştırıcı tarafindan da belirtilmiștir (Hughes 1981, Albertch ve Kohlenbach 1989, Matheson ve ark. 1990, Mirici 2000).

In vitro çalışmalarda, adventif sürgün rejenerasyonunu en fazla etkileyen faktörlerden bir tanesi de ortamda bulunan bitki büyümesini düzenleyiciler olduğu ve besin ortamındaki oksin-sitokinin dengesinin iyi ayarlanması naticesinde yoksek oranda adventif sorgùn rejenerasyonunun elde edilebileceği değişik araștıncılar tarafindan bildirilmiştir (Özcan ve ark. 1993, Ozcan ve ark. 1996. Sancak 1999). Benzer sonuçlar bu çalışmada da elde edilmiștir.

Köklenme: Rejenere olan sürgünler 1-2 cm uzuniuğuna geldiklerinde kesilerek $0.50,1.00,1.50,2,00$ ve $2.50 \mathrm{mg} / \mathrm{IBA}$ içeren $\mathrm{MS}$ besin ortamlarında köklendirilmeye alınmıştır. Kültür başlangıcından uģ hafta sonra kök oluşturan sürglin o!anı, sürgün başına kök sayısı kaydedilmiștir. Kök oluşturan sürgún oranı ve sürglun başına kök sayısında kullanılan ortamlar arasında farklilik gözlenmiştir (Çizelge 3; $p<0,01$ ). En yüksek kŏklenme oranı \% 100.00 ile $2.5 \mathrm{mg} / \mathrm{l}$ iBA içeren $\mathrm{MS}$ besin ortamindan elde edilmiştir. Bununla birfikte $\% 80.00$ ile 2 mg/ IBA içeren MS besin ortamndan elde edilen değer ile arasındaki fark istatistiksel açıdan önemsiz çıkmıştır, Sürgün başina en fazla kök sayısı 4,40 adet ile $2,5 \mathrm{mg} /$ IBA içeren MS besin ortamindan elde odilmiştir. Köklenen sürgdriler daha sonra saksilara aktanlarak serado geliştirilmiştır. 
Çizelge 3. Farklı IBA konsantrasyonlarının Kubilay ceşidinden elde edilen adventif sürgünlerin kōklenmesi üzerine etkisi

\begin{tabular}{|c|c|c|}
\hline $\begin{array}{l}\text { 1BA Dozlan! } \\
\text { (mg/l) }\end{array}$ & $\begin{array}{c}\text { Kök oluşturan sürgün } \\
\text { orani (\%) }\end{array}$ & $\begin{array}{l}\text { Sürgün başına kük } \\
\text { sayısı (adet) }\end{array}$ \\
\hline 0.5 & $53.33 b^{*}$ & $1.55 \mathrm{C}$ \\
\hline 1 & $73.33 \mathrm{~b}$ & $2.33 \mathrm{bc}$ \\
\hline 1.50 & $46.66 \mathrm{~b}$ & $2.08 \mathrm{bc}$ \\
\hline 2 & $80.00 \mathrm{ab}$ & $2.73 \mathrm{~b}$ \\
\hline 2.5 & $100: 00 \mathrm{a}$ & $4.40 \mathrm{a}$ \\
\hline
\end{tabular}

: aynı sütun içerisinde farklı harflerle gösterilen

ortalamalar arasındaki fark $p<0.05$ dozeyinde önemlidir

Farklı bitki türlerinin en iyi köklendiği boyuüme düzenleyicisi farkı olabilmektedir. Onceki çalışmalarda mercimek 0.25 mg// IBA (Khawar ve Ozcan 2002), Macar fiği $5 \mu$ M IBA (Sancak ve ark. 2000), korunga $1 \mathrm{mg} / \mathrm{I} I \mathrm{BA}$ veya $1 \mathrm{mg} / \mathrm{I}$ NAA (Özcan ve ark. 1996), çilek uçgulu 1-4 mg/l IAA (Singha ve ark. 1988), Nohut $1 \mu \mathrm{M}$ IBA ve Bezelye ise $2 \mathrm{mg} / \mathrm{I}$ IAA içeren besin ortaminda (Hussey ve Gunn 1984) en iyi köklenme göstermiştir. Bu çalışmada ise en iyi köklenme $2.5 \mathrm{mg} / \mathrm{IBA}$ içeren besin ortamından elde edilmiştir.

\section{Sonuç}

Optimize edilmiş bir rejenerasyon sistemine sahip olmayan bir türde transformasyon yapmanin fazla bir anlamı olmadığından ve bütün bitki türleri için evrensel bir rejenerasyon protokolù olmayıșı nedeniyle her bitki türü hatta her bitki çeşidi için spesifik bir sistemin belirlenmesi gerekmektedir. Bu nedenle, bu çalışma ile ulke tarımı için son derece önemli olan fiğ çeşitlerinde gen aktarımına uygun bir adventif sürgün rejenerasyonu sistemi geliştirilmiş ve çeşitlere göre değişmekle beraber \%095.00 arasında bir rejenerasyon frekansı yakalanmıs ve elde edilen sürgünler köklendirilerek saksilara aktarılmıştır. Araştırma sonuçlarımıza göre, en yüksek rejenerasyonu incelenen 8 farkli fiğ çeşidinden Kubilay çeşidi, en düşük rejenerasyonu ise Karaetçi çeşidi vermiştir. Buna dayanarak Kubilay çeşidinin rejenerasyon kapasitesinin diğer çeşitlerden daha yüksek olduğu ve transformasyon çalışmalarında bu çeșidin kullanılabileceği sonucuna varilabilir. Bundan sonraki amacimiz ise Agrobacterium tumefaciens veya diğer gen aktarımı teknikleriyle transgenik fiğ bitkilerinin elde edilmesidir.

\section{Teşekkür}

Bu çalışma 88K120640 kodlu DPT Tarımsal Biyoteknoloji AR-GE Merkezi Projesi tarafindan desteklenmiștir.

\section{Kaynaklar}

Açikgöz, E, 1991 . Yem Bitkileri, Uludağ Oniv, Yay. No:7-0250210, Bursa.

Albrecht, C. and H. W. Kohlenbach, 1989. Induction of somatic embryogenesis in leaf-derived callus of Vicia narbonersis L., Plant Cell Rep., 8. 267-269.
Anonim, 1999, Devlet Istafistik Enstitùsū, Başbakanlik. Ankara.

Hughes, K.W, 1981, Omamental Species, pp 5-50. In: Cloning Agricultural Plants Via In Vitro Techniques, Conger, B. V. (ed.), CRC Press, Boca Raton, Florida.

Hussey, G. and H. V. Gunn, 1984. Plant production in pea (Pisum sativum L. cvs. Puget and Upton) from long-term callus with superficial meristems. Plant Sci. Let. $37,143-148$.

Khawar, M. K, and S. Ozcan, 2002. Effect of Indole-3-butyric acid on in vitro root development in lentil (Lens culinaris Medik.) Turk J. Bot., 26, 109-111.

Lazzeri, P. A, D. F. Hildebrand, G. B. Collins, 1987, Soybean somatic embriyogenesis: Efects of hormones and culture manipulations. Plant Cell Tiss. Org. Cult, 10 (197-208)

Matheson, S. L., J. Nowak and L. N. MacLean, 1990. Selection of regenerative genotypes from highly productive cuitivars of alfalfa Euphytica, 45, 105-112.

Mirici, S. 2000. Kolza (Brassica napus L ssp. Oleifera) Bitkisinde Adventif Sörgün Rejenerasyonu ve Agrobacterium tumefaciens Aracıliğıyla Gen Aktarımı. Doktora Tezi, Gazi Oniv. Fen Bilimleri Enstitüsí, Ankara.

Murashige, T. and F. Skoog, 1962, A revised medium for rapid growth and bioassays with tobacco tissue cultures, Physiol. Plant., 15, 473-497.

Natali, L. and A. Cavallini, 1987. Regeneration of pea (Pisum sativum L.) plantlets by in vitro culture of immalure embriyos. Plant Breed., 99,172-176.

Singha, S., B. S. Baker and S. K. Bhatia, 1988. Tissue culture propagation of running buffalo clover (Trifolium stolaniferum Muhl. ex A. Eatton). Plant Cell, Tiss. Org. Cult., 15, 9-11.

Ozcan, S., M. Barghchi, S. Firek and J. Draper, 1993. Efficient adventitious shoot regeneration and somatic embriyogenesis in pea. Plant Cell Tiss, Org. Cuit., 11, 4447.

Ozcan, S, ve M. Ozgen, 1996. Bitki genetik mühendisliği. Kukem Dergisi, 1, 69-95.

Ozcan, S., C. S. Sevimay, M. Yıldız, C. Sancak and M. Ozgen, 1996. Prolific shoot regeneration from immature embriyo explants of sainfoin (Onobrychis viclifolia Scop.), Plant Cell Rep., 16, 200-203.

Sağlamtimur, T., V. Tansı, H. Baytekin, 1990. Yem Bitkileri Yetiştime. Cukurova Úniv, Ziraat Fak. Ders Kitabı No: 74. Adana.

Sancak C. 1999. Koca fiğ (Vicio narbonensis L.) in olguniașmamiş embriyo eksplantlanından adventif sủrgün rejenerasyonu, Gazi Eğitim Fak. Dergisi, 19, 25-33.

Sancak, C., S. Mirici and S. Ózcan, 2000. High frequency shoot rejeneration from immature embriyo explants of Hungarian vetch, Plant Cell, Tiss. Org. Cult., 61, 231-235.

Snedecor, G, W and W. G. Cochran, 1967. Statistical Methods. The Lowa State University Press, lowa, USA.

Soya, H. 1991, Fiğ Kulturo. TrVAP Ege Marmara Dilimi Tarla Bitkileri ABAV Toplantısi. 24-26. 10. 1991. Ege Tar. Araș. Enst. Menemen, Izmir.

lietişim adresi:

Cengiz SANCAK

Ankara Univ. Ziraat Fak. Tarla Bitkileri BollumU-Ankara

Tel: 031231705 50/1618

Fax: 03123182666

E-mail: sancak@agri.anikara.edu.tr. 